\title{
Aadhaar: Its Implementation and Implications
}

\author{
Z Zakhar Naved* and Isha Kaushal ${ }^{\dagger}$
}

\begin{abstract}
In the light of almost every welfare and non-welfare scheme mandating Aadhaar, it becomes imperative to consider its inevitable implications. The Aadhaar, which was initially conceived for the benefit of BPL families, has been for over a decade forced upon every resident of India. The Supreme Court, in its judgement, while assenting Aadhaar, has adequately addressed the apprehension of the petitioners by striking off or reading down the impugned provisions which invariably set a new legislative agenda for the Parliament. Thus, this Paper attempts to analyse the provisions of Aadhaar, and the legal implications emanating there from. Through this paper, the authors will strenuously aver that though UID was initiated with the objective of streamlining the distribution of basic and fundamental services to the weaker sections, it has now turned into an all pervasive tool which has the potential of arming the Government, private corporate players and hackers with sensitive data.
\end{abstract}

Keywords: Aadhaar, Government, Privacy, Supreme Court, UIDAI

* Faculty of Law, Jamia Millia Islamia University, New Delhi, India; zakhar1996@gmail.com

${ }^{\dagger}$ Faculty of Law, Jamia Millia Islamia University, New Delhi, India; kaushal.isha19@gmail.com 


\section{Introduction}

Aadhaar has been aptly dubbed as 'Schrodinger's Aadhaar'1, as on the one hand, the legislation spells out that it is merely voluntary in nature, whereas on the other hand, the increasing appetite of the Government to include a multiplicity of schemes under the umbrella of Aadhaar, had made it, without a shadow of doubt, inescapable. It had become the only gateway, to access Government and private services- from welfare schemes such as mid-day meal, ${ }^{2}$ pensions of retired Defence Forces, ${ }^{3}$ and scholarships, ${ }^{4}$ to nonwelfare schemes including PAN card, ${ }^{5}$ bank accounts, ${ }^{6}$ registration for NEET-20177and mobile verification. ${ }^{8}$ The issuance of 139 notifications ${ }^{9}$ in this regard, solidified the omnipotence of Aadhaar.

1 Rochelle D' Souza, Schrodinger's Aadhaar, https://www.magzter.com/ articles/10238/254488/5a1f1db4c4db8 (last accessed on 29th October, 2018).

2 Ministry of Human Resource Development, Notifications under Section 7 of Aadhaar Act,2016 for Mid day meal scheme, http://mdm.nic.in/ Files/CCH_Notification/Gazette\%20Notification-CCH-MDM-28-22017.pdf(last accessed on 15 ${ }^{\text {th }}$ April, 2018).

3 Department of Ex-Servicemen Welfare, Ministry of Defence, Notification S.O. 747 (E),http://egazette.nic.in/WriteReadData/2017/174639.pdf (last accessed on $15^{\text {th }}$ April, 2018).

4 University Grants Commission D.O. No. F. 8-2/2016, www.ugc.ac.in/pdfnews/4792000_Aadhaar-.pdf (last accessed on 15 $15^{\text {th }}$ April, 2018).

5 The Finance Act, §56, No. 7, Acts of Parliament, 2017 (India).

6Prevention of Money-laundering (Maintenance of Records) Second Amendment Rules, 2017, Ministry of Finance, http:/ / egazette.nic.in/WriteReadData/2017/176407.pdf (last accessed on $15^{\text {th }}$ April, 2018).

7 Central Board of Secondary Education, ,Requirement of Aadhaar for applicants of NEET-2017, http://cbse.nic.in/newsite/ attach/ NOTIFICATIN\%20FOR\%20AADHAR-final.pdf (last accessed on $15^{\text {th }}$ April, 2018).

8, Ministry of Communications Access Services Cell File No 800-26/2016-AS II, http://www.dot.gov.in/sites/default/files/Re-verification\% 20 extension.PDF (last accessed on 15 $5^{\text {th }}$ April, 2018).

9 Mehal Jain, SC extends deadline for mandatory linkage of Aadhaar with all schemes and services to March 31, Live Law.in (December 15, 2017) https:// www.livelaw.in/breaking-sc-extends-deadline-mandatory- 
It perpetuates an undeniable deviation from the fundamental facet of a democratic republic, by creating a viable atmosphere to bring about a shift from 'We the people' to 'We the Government'. The State devised a scheme that compromised the individual's right to privacy, thereby, acquiring unbridled powers that, if misused, had the potential to serve as instruments for creation of a virtual panoptic. It turned into an all pervasive tool which had the potential of arming the Government, private corporate players and hackers with sensitive data.

The scope of Aadhaar (Targeted Delivery of Financial and other Subsidies, Benefits and Services) Act, 2016 (hereinafter referred to as the "Act") has been considerably restricted by therecent, mammoth judgment of Supreme Court in the case of Justice K.S. Puttaswamy (Retd.) and Ors. v. Union of India and Ors. ${ }^{10}$ (hereinafter referred to as "Aadhaar judgment"). While upholding the legitimacy of Aadhaar by 4:1 majority, the Supreme Court held that the Act passes the muster of the three-fold test as formulated in Justice K.S. Puttaswamy(Retd.) and Ors. v. Union of India and Ors.11 (hereinafter referred to as "Privacy judgment"), and more importantly, meets the test of proportionality whose principles seek to safeguard citizens from excessive Government measures. ${ }^{12}$ As opposed to the four judges who labelled Aadhaar as constitutionally valid, the vehement dissent of Justice Dr. D.Y.Chandrachud, strikes a note of caution against the structure of Aadhaar. It would be safe to conclude that his argument was the lynchpin that propelled the final judgement given the fierceness and the conviction with which the opinion was presented. Dissent 'cancels the monolithic solidarity' on which the authority of court depends. ${ }^{13}$

linkage-aadhaar-schemes-services-march-31/ (last accessed on 22nd August, 2018).

102018 S.C.C. OnLine S.C. 1642.

11 (2017) 10 S.C.C. 1.

12 Supra note 10.

13 Learned Hand, The Bill of Rights, 72 Harvard University Press, 1958. See also Krithika Ashok, Disinclined to Dissent? A Study of Supreme Court of India, Vol. 1 Indian Law Review 7, $11 \quad$ (2017) http://dspace.jgu.edu.in:8080/ jspui/bitstream/ 10739/941/1/ Disinclined $\%$ 20to\%20dissent \%20A\%20study\%20of $\% 20$ the $\% 20$ 


\section{Background and Legal Lacunas}

In order to comprehend the implications of Aadhaar, it would be fitting to trace the development of the scheme from its inception to its end. The concept of Unique Identification (UID) was first conceived in 2006, when the administrative approval for 'Unique ID for Below Poverty Line (BPL) families' was given by the Department of Information Technology and the Ministry of Communications and Information Technology. Although this scheme was originally intended for BPL families, it has been gradually extended to all the citizens of India, making it mandatory for availing amyriad of welfare and non-welfare schemes.

In due course, a Processes Committee was set up to suggest processes for the upgradation, modification, addition and deletion of data fields from the core database under the project, which eventually facilitated the formation of a UID Authority. Subsequently, Empowered Group of Ministers (EGoM) was constituted, with the approval of the then Prime Minister Mr. Manmohan Singh, to review the scheme. In the course of four meetings undertaken by the EGoM, they established a UID Authority as an executive Authority under the Planning Commission for five years; after the completion of which, a decision was to be taken in relation to the location of the Unique Identification Authority of India (hereinafter referred to as "UIDAI")

Ultimately, the UIDAI was constituted in pursuance of the executive powers of the Government on 28 th January, 2009 as an attached office under the aegis of the Planning Commission. ${ }^{14}$ The reason behind not bestowing UIDAI with statutory status at the time of its initiation, according to the Ministry of Planning, was to ensure better coordination with different departments. ${ }^{15}$ However,

Supreme \%20Court $\% 20$ of $\% 20$ India.pdf (last accessed on: $5^{\text {th }}$ October, 2018).

14 Planning Commission, Government of India, Notification No. A43011/02/2009 Admn. I, https://uidai.gov.in/ images/ notification _28_ jan_2009.pdf (last accessed on $6^{\text {th }}$ April, 2018).

15 Standing Committee on Finance, Lok Sabha, The National Identification Authority 
keeping in mind that the Government was attempting to create the world's largest biometric database based on the national identity project, this rationale seems both implausible and confounding. Be that as it may, the UIDAI started enrolling residents after obtaining their demographic and biometric data. Intriguingly, this was being done in the absence of any robust framework for protection of such vast and sensitive data.

An important question that arises in this context is, regarding the authority that was vested in the UIDAI to carry out its operations, since its inception. The Ministry of Planning justified their authority by stating that there were no legal constraints in the collection of such data, since the powers of the Executive are coextensive with that of the legislature. ${ }^{16}$ However, as a point of information, it is pertinent to note that this reasoning did not satiate the Standing Committee on Finance, ${ }^{17}$ since the bill regarding the same was underway in Parliament.

The National Identification Authority of India Bill, 2010 failed to pass in the Parliament, particularly after the Parliamentary Standing Committee on Finance, rejected the Bill and urged the Government to reconsider and review the UID scheme. However, disregarding the recommendation, the Government continued enrolling residents under the Aadhaar scheme, in the exercise of their executive powers, before the Act was passed in2016. At this juncture, it becomes indispensable to consider the legitimacy of such erstwhile actions taken by the Central Government which have been, incidentally, retrospectively validated by Section 59 of the Act. The absence of a legislative framework for the Aadhaar project between 2009 and 2016, left the biometric data of millions of Indian citizens bereft of the protection that the sensitivity of the data collected necessitates, in order to comprehensively protect and enforce the right to privacy. ${ }^{18}$ Despite this, the majority in the Aadhaar verdict did not invalidate the enrolments that were made prior to the passing of this Act. In comparison to the expenditure

http://www.prsindia.org/uploads/media/UID/uid\%20report.pdf (last accessed on $4^{\text {th }}$ March, 2018).

${ }^{16} I d$.

${ }^{17} I d$.

${ }^{18 \text { Supra note } 10 .}$ 
that would inevitably be incurred in repeating the enrolment process, the costs of validating Section 59 was considerably less and therefore deemed to be more feasible. In order to keep the validation (of Section 59) in line with democratic ideals, the court ordered the elicitation of 'consent' from every person who was enrolled prior to the passing of the Act. ${ }^{19}$ However, the court remained silent on the manner in which the said consent is to be elicited. In the Aadhaar Handbook of $2010^{20}$ and 201321, the following guideline finds mention:

"In the interest of transparency, it is recommended that the Registrar inform the resident that they will be keeping the biometric data and also define how the data will be used and how it will be kept secure".

Since the handbook is merely 'recommendatory' in nature, it has no binding effect on the Registrar. Thus, a reasonable speculation of the consent obtained and its potential illegality arises. The importance of an informed consent has more to it, than meets the eye. Justice A.P. Shah, the Privacy judgment, and the Justice B.N. Srikrishna Committee Report, highlight and stress on the importance of informed consent making it the primary basis to process personal data must be individual consent. ${ }^{22}$

Furthermore, the Act was passed during the Budget Session, when the matter pertaining to Aadhaar was still pending before the Supreme Court. The Parliament evidently did not supersede its powers as the rule of sub judice fails to apply ${ }^{23}$. To draw an analogy,

\footnotetext{
${ }^{19}$ Supra note 10.

20 UIDAI (Planning Commission), Aadhaar Handbook for Registrars (2010),

http:/ /indiamicrofinance.com/wp-content/uploads/2010/08/AadhaarHandbook. pdf, at page 11 (last accessed on 9th October, 2018).

${ }^{21}$ UIDAI (Planning Commission), Aadhaar Handbook for Registrars (2013) https:/ / archive.org/stream/aadhaar_handbook_registrars_v3_04062013/ aadhaar_handbook_registrars_v3_04062013_djvu.txt (last accssed on 9 ${ }^{\text {th }}$ October 2018).

22Infra note 124.

23 Chapter 26- General Rules of Procedure, Rajya Sabha at Work 772, 775 https://rajyasabha.nic.in/rsnew/rsat_work/archive/chapter-26.pdf (last accessed on 20th September, 2018).
} 
the representative case of Muslim Women (Protection of Rights on Divorce) Bill, 1986 may be taken, where objections were raised regarding the consideration of the Bill, when the matter in relation to it, was still pending before the Court. The Chairman, in the aforementioned case, ruled that 'sovereign bodies have the power to legislate on any matter, irrespective of its pending status before a Court'24 An argument was brought out along the same lines with respect to the passing of the Aadhaar Bill, stating that the pendency of a challenge regarding an Executive action, in front of the Supreme Court, does not suspend the right of the Parliament to legislate. ${ }^{25}$

Nonetheless, the question as to whether the Government was justified in introducing Aadhaar as a Money Bill demands consideration. Passing the legislation as a Money Bill secured the successful passage of the Bill by bringing it under the ambit of the special procedure that is elucidated under Article 109 of the Constitution of India; that gives the Rajya Sabha's recommendations a mere persuasive value as opposed to a binding one. The introduction of the Bill as a Money Bill, did not require the reference of the Parliamentary Committee, which was unjustified since a further deliberation by such a Committee would have undoubtedly strengthened the mechanism of the largest biometric database such as Aadhaar. The Aadhaar judgment by a majority validated the passing of the Bill as a Money Bill by opining that Section 7 of the Act was the "core provision" and that the residuary provisions were merely incidental to it. ${ }^{26}$ In contrast, the rational employed in the dissenting opinion is much more compelling - the main object of the Act was to create a national identity, and even though the Preamble succeeding in colouring the legislation as a Money Bill with shrew drafting, the substantive provisions of the Act do not conform to the object specified in Preamble and thus travel far beyond the boundaries of a Money Bill. ${ }^{27}$ Section 7 was

\footnotetext{
${ }^{24} I d$.

25 Statement by Mr. Arun Jaitley, The Aadhaar (Targeted Delivery of Financial and Other Subsidies, Benefits and Services) Bill, 2016, Rajya Sabha $(16 / 03 / 2016)$.

26Supra note 10 .

27 Supra note 10.
} 
opined to simply be a provision that imposes a requirement for authentication. For this reason, it was remarked that such action of superseding the authority of Rajya Sabha "constitutes a fraud on the Constitution."Moreover, Section 57 of the Act does not justify the passage of the Bill as a Money Bill. This provision in variably opens a Pandora's Box, for, the introduction of corporate bodies into the equation will inevitably intrude into the pre-established trustee relationship between the Government and its citizens, especially when sensitive information is involved. While briefly touching on this point in the Lok Sabha, the Hon'ble Finance Minister, Mr. Arun Jaitley stated that, he could not bar other authorities. ${ }^{28} \mathrm{In}$ fact, an Amendment to the bill was recommended by the Rajya Sabha for the deletion of the said provision. However, the recommendation was rejected. Although the Aadhaar judgment reflects that section 57, in its current form, will be susceptible to commercial exploitation; all three opinions manifest a varied degree of disinclination towards the section as it stands. Dr. D.Y. Chandrachud, while being conscious of the fact that the impugned section may also lead to "individual profiling" held that the section altogether does not pass the constitutional muster, and that the Parliament has travelled far beyond its stated purpose in the Preamble of the Act. On the other hand, the concurring opinion holds only part of section 57 unconstitutional, in as much as it allows establishing the identity of a resident pursuant to 'any contract' to this effect. The majority opinion intriguingly reflects substantial lack of clarity on the fate of section 57 . Consequently, this has given rise to confusion, which has resulted in speculations regarding the role of corporate bodies, which will continue to loom over, until definite instructions are issued from the concerned Ministries/ Regulatory Authorities. ${ }^{29}$ The root of this confusion is embedded in the judgment itself, as the majority opinion at various instances mentions that only 'a portion' or 'a part of' section 57 is

28 Statement by Mr. Arun Jaitley, The Aadhaar (Targeted Delivery of Financial and Other Subsidies, Benefits and Services) Bill, 2016, Lok Sabha (11/03/2016).

29 Samarth Bansal, Supreme Court Judgment on Aadhaar leads to confusion in private sector, Hindustan Times (September, 27th, 2018) (last accessed on 28 $8^{\text {th }}$ September, 2018). 
held unconstitutional, without spelling out the unconstitutional facets definitely.

Insofar as Section 57 in the present form is concerned, it is susceptible to misuse inasmuch as: (a) It can be used for establishing the identity of an individual 'for any purpose'. We read down this provision to mean that such a purpose has to be backed by law. Further, whenever any such "law" is made, it would be subject to judicial scrutiny. (b) Such purpose is not limited pursuant to any law alone but can be done pursuant to 'any contract to this effect' as well. This is clearly impermissible as a contractual provision is not backed by a law and, therefore, first requirement of proportionality test is not met. (c) Apart from authorising the State, even 'any body corporate or person' is authorised to avail authentication services which can be on the basis of purported agreement between an individual and such body corporate or person. Even if we presume that legislature did not intend so, the impact of the aforesaid features would be to enable commercial exploitation of an individual biometric and demographic information by the private entities. Thus, this part of the provision which enables body corporate and individuals also to seek authentication, that too on the basis of a contract between the individual and such body corporate or person, would impinge upon the right to privacy of such individuals. This part of the section, thus, is declared unconstitutional. 30

The court having merely narrowed the ambit of the first leg of section 57, has not held it unconstitutional in toto. Although, the role of corporate bodies in seeking authentication 'pursuant to a contract' has been held unconstitutional, the irrepressible question that arises is whether corporate bodies will be restricted in seeking authentication, when it is backed by a law. The patent assertion in the judgment that "if a person voluntary offers Aadhaar card as a proof of his/her identity, there may not be a problem" insinuates that corporate bodies may not be completely forbidden from using Aadhaar. This undoubtedly leaves a new legislative agenda for the Parliament.

30Supra note 10. 


\section{Supreme Court on Aadhaar}

Aadhaar's journey has been a roller coaster ride, right from its inception, which has resulted in a tussle between the Judiciary and Legislature. Prior to the inception of the Act, the Supreme Court was against mandating Aadhaar. The first order of the Court in this regard was on23rdSeptember, 2013, when it directed that no person shall suffer due to the non-possession of Aadhaar, in spite of various circulars making it mandatory. ${ }^{31}$ Then, in March 2015, a 3Judges bench, while noting that despite its previous order, Aadhaar identification is being insisted upon by various authorities, asked the Union of India, States, and all their functionaries to abide by their previous order dated 23rd September, 2013.32Further, in March, 2014, the Supreme Court directed that no person shall be deprived of any service for want of Aadhaar number, in case he/she is otherwise eligible/entitled. And accordingly, all the authorities were directed to modify their forms/circulars/likes so as to not compulsorily require the Aadhaar number, in order to meet the requirement of the interim order passed by the Court. ${ }^{33}$ In August, 2015, the Court further directed the Government to inter alia convey, using electronic and print media, that the obtaining of Aadhaar is not mandatory and, that the production of Aadhaar shall not be a condition precedent for availing any benefit that is otherwise due. ${ }^{34}$ Finally, in October, 2015, the Court while impressing upon the respondents to strictly follow its previous orders, stated that the Aadhaar scheme is purely voluntary 'and cannot be made mandatory' till the matter is finally decided by the Court, one way or the other. ${ }^{35}$

Even after the commencement of the Act, the Supreme Court retained its earlier view. In its order dated $14^{\text {th }}$ September, 2016, in

31 Justice K.S. Puttaswamy (Retd.) v. Union of India, 2013 (12) SCALE 232. (India)

32 Justice K.S. Puttaswamy (Retd.) v. Union of India, MANU/SCOR/22662/2015.

33 Unique Identification Authority of India v. Central Bureau of Investigation, (2017) 7 S.C.C. 157.

34 Justice K.S. Puttaswamy (Retd.) v. Union of India, 2015 (8) SCALE 747.

35 Justice K.S. Puttaswamy (Retd.) v. Union of India, MANU/SCOR/11831/2015. 
the case of All Bengal Minority Students Council v. Union of India,36 the Supreme Court while taking note of the order in October, 2015, stayed the operation and the implementation of impugned letters mandating Aadhaar for pre-matric, post-matric and merit-cummeans scholarships. Subsequently, the Supreme Court appeared to be nonchalant when the Government brazenly violated its order. However, the Supreme Court's view started shifting, when vide its order dated 6 $6^{\text {th }}$ February, 2017 in Lokniti Foundation v. Union of India and Ors., ${ }^{37}$ gave its approval to the Government for the reverification of the existing subscribers using Aadhaar. Intriguingly, this order failed to consider and reflect the previous orders given in relation to Aadhaar.

Ultimately, the Court rendered a judgment in favour of Aadhaar when it upheld the constitutional validity of Section 139AA of Income Tax Act, 1961 as introduced by the Finance Act, 201738 which mandated the linking of Aadhaar-PAN as a prerequisite to file an income tax return. However, in the case of Binoy Viswam v. Union of India, ${ }^{39 J}$ Justice A.K. Sikri, and Justice Ashok Bhushan had partially put a stay on this provision and directed that unless the question of the right to privacy is decided, which was at that time pending before the Constitutional Bench, only a prospective effect shall be given to it. The question which arose for consideration in this case inter alia was whether the impugned provision i.e. section 139AA of Income Tax Act, 1961 violated Article 14 and 19(1)(g) of the Constitution which the Court answered in the negative.

Apart from this, an important question which was addressed in Binoy Viswam ${ }^{40}$ was whether the procuring of Aadhaar was optional or obligatory. This issue arose because of the opposing views of the parties pertaining to the true interpretation of proviso to section 7 of the Act. On the one hand, the petitioners contended that this proviso, which offers an alternate and viable means of identification, implies that the Act is voluntary, while on the other

\footnotetext{
${ }^{36}$ MANU/SCOR/20730/2016.

372017 (6) SCALE 698.

${ }^{38}$ Supra note 5.

39 (2017) 7 S.C.C. 59. (India)

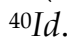


hand, the respondents were of the view that this proviso is only an interim measure in a scenario where the Aadhaar application has been made but the individual has not yet received the Aadhaar number. Furthermore, there was bedlam in the Courtroom as to whether the Government can make Aadhaar voluntary under the Aadhaar Act, while simultaneously mandating it under the Income Tax Act, 1961. The Court, after pondering upon whether the two statutes should be harmoniously construed, finally buried the hatchet by observing that "it is the prerogative of the Parliament to make a particular provision directory in one statute and mandatory/compulsory in other."While holding so, the Court relied on the judgment in the case of Municipal Corporation of Delhi v. Shiv Shankert1 wherein it was held that if the object of the two statutes is different and the language of both is restricted to its own object, then they are intended to run on parallel lines and there would be no real conflict even though it may appear to be so on the surface. Similarly, the impugned section is only repugnant to the provision of the Aadhaar Act. Since there is a presumption against the doctrine of implied repeal and the two provisions are not 'irreconcilable' per se, the Court was judicious in holding that there is no implied repeal in the instant case.

Additionally, an argument put forth by the petitioners before the benches in Binoy Viswam and Aadhaar judgment was that the spate of administrative orders under section 7 of the Act are violative of the previous orders of the court which repeatedly opined that Aadhaar should not be made mandatory. The argument failed to impress upon the Court, since it was of the opinion that the earlier orders were in respect of the Aadhaar 'scheme' and not the statute. The majority opinion in the Aadhaar judgment was of the same view and endorsed the reasoning given in BinoyViswam judgment. It is, however, pertinent to note that both BinoyViswamand majority opinion in the Aadhaar judgment again failed to take into consideration the order in All Bengal Minority Student Council, ${ }^{42}$ which was pronounced after the Act came into force. At the same time, the bench in Aadhaar judgment was also of the view that it would have been better, had a clarification been obtained

41 (1971) 1 S.C.C. 442.

42Supra note 36. 
from the Court after the passing of the Aadhaar Act before issuing such circulars and orders.

The lone dissenter in the Aadhaar judgment, Justice Dr. DY Chandrachud, expressed serious concerns over the disobedience of the interim orders of Supreme Court. The orders of the Court are not recommendatory - they are binding directions of a constitutional adjudicator. ${ }^{43} \mathrm{He}$ categorically stated that, "If we were not to enforce a punctilious compliance with our own directions by government, that would ring a death - knell of the institutional position of the Supreme Court." 44 After all, interim orders are based on prima facie findings to ensure that the matter does not become either infructuous or fait accompli before the final hearing. ${ }^{45}$

\section{Issue of Privacy}

\subsection{Concerns}

P.N. Bhagwati, J. has rightly opined that Article 21 is of the 'widest amplitude', ${ }^{46}$ and its rippling effect can be seen in the Supreme Court's historic and unanimous judgment declaring right to privacy as a part and parcel of Article 21. Right to privacy, in its simplest sense, allows each human being to be left alone in a core which is inviolable. ${ }^{47}$ However, Aadhaar in its initial form was doing the exact opposite. It was becoming a bridge across our data, leading towards the establishment of a digital colony, which is susceptible to blitz, at the hands of hackers. The report based on the study conducted by The Centre for Internet and Society, a nonprofit organisation, further shows the vulnerability of such data. It was estimated that 130-135 million Aadhaar numbers have been leaked and estimated the bank account number leaks around 100 million. ${ }^{48}$ Moreover, in the Lok Sabha's unstarred question no. 574

\footnotetext{
43Supra note 10.

44 Supra note 10.

45 State of Assam v. Barak Upatyaka, (2009) 5 S.C.C. 694.

46Maneka Gandhi v. Union of India, 1978 A.I.R. S.C. 597.

47 Justice K.S. Puttaswamy (Retd.) v. Union of India, (2017) 10 S.C.C. 1.

48 Amber Sinha and Srinivas Kodali, Information Security Practices of Aadhaar (or lack thereof), The Centre for Internet and Society 3, (May 2017),
} 
dated 19th July 2017, the Minister of State for Electronics and Information Technology while replying to a query posed, regarding the leakage of Aadhaar data, stated that, "it has been found that 210 websites of the Central Government and State Government Departments including educational institutions, displayed the list of beneficiaries along with their name, addresses, other details and Aadhaar numbers for the information of general public."Instances of adverse effect on informational privacy at hands of corporate bodies are numerous. It was reported that in July, 2017, there was a breach in the data of Jio users that was posted on a website named magicapk.com.49. Furthermore, allegations had been levelled against Bharti Airtel and Airtel Payment Bank bringing out that at the time of mobile verification using Aadhaar based e-KYC, Airtel retailers opened Airtel Payment Bank accounts, without the informed consent of the users. Besides, Government's LPG subsidies were also being transferred to these accounts. As a result, more than 23 lakh customers had reportedly received as much as Rs. 47 crore in their Airtel bank accounts, the existence of which they were not aware of. Ultimately, after much ado, UIDAI through its interim order, temporarily barred Bharti Airtel and Airtel Payment Bank from conducting Aadhaar based SIM verification using e-KYC, and also e-KYC bank payments to clients.50The resentment towards Aadhaar is essentially for the initial form in which it was formulated, which in the absence of any privacy legislation is compulsive and unbolted. The Delhi High

https:/ / cis-india.org/internet.../information-security-practices-ofaadhaar-or-lack-there (last accessed on 28th March, 2018).

49 Tech Desk, Reliance Jio data breach: Here's why it is a big deal, what it means for users and more, Indian Express, (July 11 ${ }^{\text {th }}, 2017$ ) https:/ /indianexpress.com/article/technology/tech-newstechnology/reliance-jio-data-breached-120-million-users-why-it-matterswhat-it-means-for-you-and-everything-to-know-4743592/ (last accessed on $17^{\text {th }}$ July, 2018).

50 PTI, UIDAI suspends Airtel, Airtel Payment Bank's Ekyclicence, The Hindu, (December $16^{\text {th }}$, 2017) https://www.thehindu.com/business/Industry/uidai-suspends-airtelairtel-payments-banks-ekyc-licence/article21822439.ece (last accessed on 17th March, 2018). 
Court, in September, 2018, issued a suomotu PIL. ${ }^{51}$ A few FIRs were brought to the attention of the Court that highlighted as to how, during the Aadhaar verification, the accused on the pretext that the thumb impression was not obtained properly, took another one. This, along with the copy of the documents, was used to issue another SIM, which was then used in facilitating identity theft and identity fraud. In a different slant, another example, showing the growing trivialness of the fundamental right to privacy, by private players is of Trust ID. It advertises itself as "India's first mobile application to help verify anyone using their Aadhaar ID in less than one minute" 52 and thus provides a "comprehensive verification service on a single platform including ID based verification, criminal background verification based on eCourt records, social media profiling based on email-id, negative news scan on a name based...".53

Furthermore, an investigation was carried out by The Tribune, a Chandigarh based English daily newspaper, which revealed that, the details of Aadhaar holders were accessible through WatsApp, via a portal made available byan anonymous seller, by simply feeding an individual's Aadhaar number, for as little as Rs. 500.54This investigative journalism was commended by famed whistle-blower Edward Snowden, a former CIA employee and NSA analyst who advocated that such records are always subject

${ }^{51}$ Manish Bansal v. State of N.C.T. of Delhi, Crl. M.A. No. 31411/ 2018 (exemption). See also, Akanksha Jain, Misuse of Aadhaar Verification, Linkage Process: HC Worried About Disastrous Consequences, Registers Suo Motu PIL, Livelaw (September 13 ${ }^{\text {th }}, 2018$ ) https://www.livelaw.in/ misuse-of-aadhaar-verification-linkage-process-hc-worried-aboutdisastrous-consequences-registers-suo-motu-pil-read-order/ (last accessed on: $10^{\text {th }}$ October, 2018).

${ }^{52}$ https:// www.trustid.in/faq (last accessed on 6 $6^{\text {th }}$ April, 2018).

${ }^{53} \mathrm{Id}$.

${ }^{54}$ Tribune Investigation, Rs 500, 10 minutes, and you have access to billion Aadhaar details, Tribune India, (January $4^{\text {th }}, 2018$ ), https://www.thehindu.com/news/national/snowden-saysprogrammes-like-aadhaar-result-in-abuse/article22403424.ece (last accessed on 17th April, 2018). 
to abuse, and insinuated that the perpetrators of UIDAI be arrested for violating the privacy of a billion Indians. .55

The court in the Aadhaar judgment took note of 'various' news reports which have reported hacking into the Aadhaar website. However, since the judges in the majority opinion took notice of those news report which surfaced after the conclusion of hearing in the Aadhaar case, and consequently, counsels could not be heard upon the veracity of such reports, the court left this aspect to the wisdom of UIDAI "in hope that Central Identities Data Repository would find out the ways and means to curb any such tendency." 56

Apart from such appalling occurrences, a whammy article on social media which caused everyone to raise an eyebrow was of the famous cricketer M.S. Dhoni, whose Aadhaar details were made public by an enrolling agency. ${ }^{57}$ In this hue, a question regarding compensation in instances involving the leakage of private information was raised in the Lok Sabha, marked as unstarred question no. 1827 dated 26 th July 2017. Mr P.P. Chaudhary, Minister of State for Electronics and Information Technologies replied that there is no proposal/provision for providing compensation to individuals in this regard. At present, the only viable option left to seek damages by the aggrieved person is by way of section $43 \mathrm{~A}$ of Information Technology Act, 2000 which provides for compensation by a "body corporate" when it fails to have "reasonable security practices and procedures." A petition has already been filed before the Delhi High Court by Prof. Shamnad Basheer, against UIDAI seeking exemplary damages for Aadhaar data breach, inter alia under

55 Sruthi Radhakrishnan, Snowden says programmes like Aadhaar result in abuse, The Hindu, (January 9th, 2018), https://www.thehindu.com/news/national/snowden-saysprogrammes-like-aadhaar-result-in-abuse/article22403424.ece (last accessed on 17th April, 2018).

56 Supra note 10.

57 Express Web Desk, MS Dhoni's Aadhaar details made public, Ravi Shankar Prasad promises action, Indian Express (March 29th, 2017), https://indianexpress.com/article/india/sakshi-dhoni-raises-privacyissue-after-ms-dhoni-aadhaar-details-made-public-on-twitter-ravishankar-prasad-promises-action-4590310/ (last accessed on18 ${ }^{\text {th }}$ April, 2018). 
section 43A of Information Technology Act, 2000.It is to be noted herein that section $43 \mathrm{~A}$ does not extend to government organisations/ agencies. ${ }^{5}$ Therefore, it seems highly unlikely that the action is likely to succeed in as much as it relates to section 43A. In any case, the High Courts in many other such proceedings were waiting for the outcome of the Supreme Court in the Aadhaar judgment, which will now guide all respective courts in similar matters. Furthermore, Justice B.N. Srikrishna Committee Report,59 which was constituted to deliberate on a broader aspect of personal data protection, has inter alia recommended that the payment of compensation, both jointly and severally, be a levied in case of breach of data fiduciaries. On a similar footing, even the dissenting opinion in the Aadhaar judgment remarked about the exigent need of providing a right to compensation. ${ }^{60}$

The citizens are being coerced to part with their core biometric information for the purpose of authentication, failing which, the entitlement to welfare benefits like scholarships, pensions, mid-day meal that they are otherwise legitimately eligible to claim, is robbed from them. Thus, the undeniable question is whether the State's authority to discharge its constitutional and statutory obligations, is conditional upon an individual parting with his or her core biometrics. The Government appears to have imposed the doctrine of 'unconstitutional condition' which means any stipulation imposed upon the grant of a Governmental privilege, which in effect requires the recipient of the privilege to relinquish some constitutional right. ${ }^{61}$ Thus, even though a resident may otherwise be legitimately entitled to a welfare benefit from the Government, he/ she can be bereft of this right merely for want of Aadhaar. It has been held in the Aadhaar judgement that the scope of 'benefits' and

58 Data Security Council of India, Reasonable Security Practices- I..T. Amendment Act, 2008, October 10 $10^{\text {th }}, 2018$ (last accessed on 11 ${ }^{\text {th }}$ October, 2018)

https://www.dsci.in/sites/default/files/Reasonable_Security_Practices_ Under_IT_Amendment_Act2008.pdf.

${ }^{59}$ Infra note 125.

60 Supra note 10.

61 The Ahemdabad St. Xavier's Society v. State of Gujarat (1974) 1 S.C.C. 717. 
'subsidies' is to be strictly construed and be limited to welfare schemes only. As a result, possession of Aadhaar cannot be a condition precedent for procurement of benefit, which is earned by an individual, including pension schemes. ${ }^{62}$ The consequences of such a compulsion were alarming, with deaths being reported, mainly from vulnerable groups, since inter alia they find themselves excluded from the Public Distribution System (PDS) for want of Aadhaar.63In a recent case, a woman was reportedly denied admission in Gurugram hospital during her labour, and consequentially was forced to give birth outside the hospital because of her inability to furnish an Aadhaar card, even though she had her Aadhaar number. ${ }^{64}$ Such incidents coupled with other factors such as electricity outage, internet connectivity issues etc., have forced the UIDAI to issue a statement saying that no essential services should be denied for want of Aadhaar and alternate identity/mechanism be provided. 65

\subsection{Insufficient Measures}

The preceding paragraphs examine the security measures taken by the Government for the protection of data, and analyse whether they are sufficient. In Lok Sabha's unstarred question no. 1758, dated 26th July, 2017, the Government has taken aid of section 70 of

\section{Supra note 10.}

63 Jean Dreze, Following the grain trail: on India's Public Distribution System, The Hindu, (January 17th, 2018) https://www.thehindu.com/ opinion/lead/following-the-grain-trail/article22451645.ece (last accessed on 21 ${ }^{\text {st }}$ March, 2018); Deepshikha Ghosh, No Aadhaar, No food? Girl, 11, died 'begging for rice', says Jharkhand family, N.D.T.V. (October 17th, 2017) https:/ / www.ndtv.com/india-news/no-aadhaar-no-food-11-year-oldgirl-died-begging-for-rice-says-jharkhand-family-1763863 (last accessed on 20th March, 2018).

64 Sakshi Dayal, No Aadhaar, Gurgaon hospital turns away woman, she gives birth right outside, Indian Express, (February 10 ${ }^{\text {th }}, \quad 2018$ ) https:/ /indianexpress.com/article/india/no-aadhaar-hospital-turns-

away-woman-she-gives-birth-right-outside-5058006/ (last accessed on 20 ${ }^{\text {th }}$ March, 2018).

65 U.I.D.A.I., Government of India, Exception handling in Public Distribution Services and other welfare schemes, Circular No. 23011/Gen/2014/LegalUIDAI (last accessed on 10th October, 2018) https:// uidai.gov.in/ images/tenders/Circular_relating_to_Exception_handling_25102017.pdf. 
The Information Technology Act, 2000,to solidify its stance on the existence of adequate measures in this regard. In accordance with this section, Central Identities Data Repository (CIDR) was declared a 'Protected System' in December 2015, ${ }^{66}$ thereby meaning that a high quantum of punishment would be meted out against anyone attempting to gain unauthorised access to CIDR. Undoubtedly, it was a step in the right direction. However, the worrisome fact remains that, other databases like that of banks, cellular companies etc. to which Aadhaar is being compulsorily linked to, are not protected. Since it is neither expedient nor feasible for the Government to declare every system as a protected system, the data will inevitably be exposed to vulnerability. Individually, these information silos may seem inconsequential. In aggregation, they disclose the nature of the personality, including food habits, language, health, hobbies, sexual preferences, friendships, ways of dress and political affiliation. ${ }^{67}$ Elaborating upon it, the dissenting opinion in Aadhaar judgment appears to provide helpful insight, by way of an international case law decided by the Federal Constitutional Court of the Federal Republic of Germany. ${ }^{68}$ It was observed therein that distinct silos of data "can be pieced together with other data collections, particularly when individual integrated information systems are built up - to add up to a partial or virtually complete personality profile." 69 The majority opinion in Aadhaar was antithetical to this. By adverting to the arguments of respondents, the majority seems to be satiated with the reasoning that merging of silos is 'prohibited'. To argue that the structure of Aadhaar can 'never' be hacked or interfered with, is a little far-fetched. Even the Pentagon can and has been hacked.70 It appears as if the dread of several

66 Department of Electronic and Information Technology, Ministry of Communications and Information Technology. NotificationG.S.R. 993(E) http:// meity.gov.in/writereaddata/files/UIDAI\% 20CII\%20notification\% 20Dec15.pdf(last accessed on 25 ${ }^{\text {th }}$ March, 2018).

${ }^{67}$ Supra note 10.

${ }^{68}$ Federal Census Act Case, (1983) BVerfGE 1.

${ }^{69}$ Supra note 10.

70 Michael Mimoso, Meet David Dworken, the teenager who hacked the Pentagon, The Christian Science Monitor (July 5th, 2016) https://www.csmonitor.com/World/Passcode/Security- 
critics is well -founded; that it is not a matter of 'if' but 'when' such sensitive data inter-linked to multiple databases might leak. Additionally, it may also be noted, that in the garb of this provision, UIDAI was able to turn down an RTI query asking for information on cases of fake and duplicate Aadhaar, on the grounds of "national security". .1

Another specious argument put forth by the Government is that, highest standards have been set with respect to protecting one's privacy, supporting their argument with the help of Section 5 and 6 of Aadhaar (Authentication) Regulations, 2016. While the former section mandatorily places a duty on the part of requesting entity to apprise the Aadhaar number holder of the alternative of submission of identity information, the latter section directs requesting entity to obtain consent of the Aadhaar number holder, in physical or electronic form, in order to maintain logs of the same. However, in India, the devil lies in implementation. The most substantial example in relation to this context is of Reliance Jio, which crossed its 100 million mark, whereby all subscribers had to authenticate through Aadhaar, before buying the SIM. On ground reality, it appears that the process had been undertaken in total contravention of the above-mentioned sections. ${ }^{72}$ It was most likely to follow as, apart from poor implementation which was without requisite oversight, there are complications in relation to these sections in itself. This is on account of the absence of any specification in the said Regulations, pertaining to defined options or procedure, which is to be given to the Aadhaar number holder,

culture/2016/0705/Meet-David-Dworken-the-teenager-who-hacked-thePentagon (last accessed on 30th August, 2018).

71 PTI, UIDAI denies information on fake Aadhaar cards, says it might affect national security, Financial Express, (June 11 ${ }^{\text {th }}, \quad 2017$ ) https:/ / www.financialexpress.com/india-news/uidai-deniesinformation-on-fake-aadhaar-cards-says-it-might-affect-nationalsecurity/712257/ (last accessed on 21 ${ }^{\text {st }}$ June, 2018).

72 Manu Subastian, Use of Aadhaar to get Mobile SIM Connections: Legal Issues Involved, Live Law.in (December 5 ${ }^{\text {th }}, 2017$ ) https:// www.livelaw.in/ use-aadhaar-get-mobile-sim-connections-legal-issuesinvolved/ (last accessed on: 2nd October, 2018). 
in such circumstances. ${ }^{73}$ The same apprehension was also exhibited in the dissenting opinion of Aadhaar judgment. ${ }^{74}$

At this point, it may be noted that section 47(1) of the Act puts a bar in nature of limitation, where a court can take cognizance of an offence punishable under the Act only on a complaint made by UIDAI or any officer/person authorised by it. The Act or the accompanying Regulations does not enumerate whether the UIDAI is required to give details of any complaint that is made, or why it chooses to drop any specific complaint which gives carte blanche to initiate criminal proceedings, while also opening doors to increased bureaucracy. In the Aadhaar judgment, while the concurring opinion of Justice Ashok Bhushan, upheld the validity of impugned provision, by interpreting it to encompass situations where UIDAI can initiate complaint on its own motion,' or at the request of an aggrieved person', the majority judgment expressed its 'hope' that the provision should be suitably amended in order to include initiation of complaint by the person, whose rights has been adversely affected. Regardless, Justice Dr. D.Y. Chandrachud, in his dissenting judgment opined that the impugned section 'violates the right to seek remedy'. It may be conceded that there are similar provisions in some other statutes akin to section 47 of the Act, whose validity has been upheld. However, as pointed out in the dissenting opinion, the fact that there is no grievance redressal mechanism, if breach is committed by UIDAI, along with the fact that UIDAI lacks requisite autonomy for its proper functioning, strikes a jarring note. This reasoning finds further substance when the functioning of the impugned provision is explored. As per the Lok Sabha's unstarred question no. 819, dated 20th December 2017, only 30 FIR's have been filed with the police, since the inception of the Act. This number is relatively miniscule, keeping in view that Mr. Ravi Shankar Prasad argued in the Rajya Sabha that since December 2016, action had been taken against a 1,000 operators

73 Amber Sinha, Analysis of Key Provisions of the Aadhaar Act Regulations, The Centre for Internet and Society, (March 31st, 2017) https://cisindia.org/internet-governance/blog/analysis-of-key-provisions-ofaadhaar-act-regulations (last accessed on: $3^{\text {rd }}$ October, 2018).

74Supra note 10. 
"who tried to pollute the system or tried to make fake Aadhaar cards". 75

For a more robust Aadhaar system, it is required that there should be minimal dependence on biometric, that is, it should only be used by UIDAI for de-duplication and third party service providers should adopt other mechanisms like OTP, PIN etc. for authentication. ${ }^{76} \mathrm{~A}$ valid concern arises against the correlation of identities across domains and the illegal tracking since the Aadhaar number is consistent in all domains. ${ }^{77}$ The introduction of a temporary and revocable 16-digit Virtual ID can certainly prove to be effective. However, owing to its temporary nature, it cannot be used to undo duplication. ${ }^{78}$ Furthermore, as decryption keys are also stored in the Aadhaar system, insider attack poses a severe threat.79 Incorporation of certain tools and techniques from the branch of computer science such as homomorphic and functional encryption, storing hash of biometric data, symmetric searchable encryption and extensions become imperative. ${ }^{80 I t}$ would prove to be beneficial to establish an independent third party, who is bestowed with the responsibility of the decryption key-keeper and auditor, under a different administrative control. ${ }^{81}$ The role of an independent key-keeper will address and diminish the threat of an insider attack, as a crucial part of the decryption key will remain solely with the third party.

75 Rajya Sabha, Short Duration Discussion, (April 10 th, 2017) http://rsdebate.nic.in/handle/123456789/670853 (last accessed on 21 ${ }^{\text {st }}$ September, 2018)

${ }^{76}$ Soumen Chakrabarti et al, A Question of Identity: What Should Aadhaar Be Like?, I.I.T. Bombay, 1, 7, https://www.cse.iitb.ac.in/ identity/ docs/aadhaar-whitepaper.pdf (last accessed on 21 st September, 2018).

77 Shweta Agrawal et al, Privacy and Security of Aadhaar: A Computer Science perspective, Computer Science and Engineering, I.I.T. Delhi, 1, 7 http://www.cse.iitd.ernet.in/ suban/reports/aadhaar.pdf (last accessed on $4^{\text {th }}$ April, 2018).

${ }^{78}$ Infra note 83.

${ }^{79}$ Supra note 77.

${ }^{80}$ Supra note 77.

${ }^{81}$ Supra note 77. 
The collection and storage of Aadhaar numbers by various entities has heightened privacy concerns ${ }^{82}$ in light of which, substantial security measures were taken by the UIDAI. Through a circular dated, 10 th January 2018, it introduced the option of Virtual ID - a temporary and revocable 16-digit random number, which could be used in lieu of the 12-digit Aadhaar number, to avail services and the issuance of a UID Token for agencies to uniquely identify their customer within their system. ${ }^{83}$ Apart from this, the said circular also entailed provisions for a Limited KYC in respect of "Local AUA's", distinct from 'Global AUA's' (Authentication User Agency). It can be amiably acknowledged that the circular was a step in the right direction, although it would have served better and effective if such measures were introduced at the time of initiation. These initiatives plays a vital role to partially alleviate security concerns for this ensures a delimitation of collection and data minimisation. However, reservations have been expressed against its effective implementation in the absence of any statutory backing. ${ }^{84}$

\section{International Scenario}

There have been several schemes similar to that of Aadhaar in other countries and the reasons behind their abandonment sets a reliable precedence of the problematic repercussions of such schemes. An illustrative instance in this regard will be of Philippines where on 12th December 1996, President Fidel Ramos issued an administrative order (A.O. No. 308) titled 'Adoption of a National Computerized Identification Reference System', in the form of an ordinance. It was primarily based on two considerations. First, the need to provide citizens and foreigners with the facility to conveniently transact business with basic services, social security providers and other Government instrumentalities, and secondly, the need to reduce, if not totally

\footnotetext{
${ }^{82}$ Infra note 83.

83 Authentication Division, UIDAI, Ministry of Electronics and Information Technology, Notification F. No. K- 11020/217/2018-UIDAI (Auth-I) https:// uidai.gov.in/ images/resource/ UIDAI_Circular _11012018.pdf (last accessed on 22nd March, 2018).

84Infra note 125 .
} 
eradicate, fraudulent transactions and misrepresentations by persons seeking basic services. The essence of A.O. No. 308 was in Section 4 which provides for a Population Reference Number (PRN) as a "common reference number to establish a linkage among concerned agencies" through the use of "Biometrics Technology" and "computer application designs.

The Supreme Court of the Republic of Philippines in an En banc session $^{85}$ held such a system void and unconstitutional. The Administrative Order No. 308violated the constitutional right to privacy and was an undue and impermissible exercise of legislative power by the Executive. Justice Reynato S. Puno, categorically stated that "the data may be gathered to aid in easing Government functions, but the existence of this vast reservoir of personal information constitutes a covert invitation to misuse, a temptation that may be too great for some of our authorities to resist." 86 Moreover, the lack of proper safeguards may interfere with the individual's liberty to abode and travel, by enabling authorities to track his movement. It has the potential to enable unscrupulous persons to access confidential information, paving the way for the violation of right against unreasonable searches and seizures, which is imposed on Governmental authorities. Administrative Order No. 308 was dangerous because it had the possibilities of intruding into the private lives of the citizens; a virtual Big Brother looking over our shoulder.

While the Court held the system to be unconstitutional, it was not a unanimous decision. Furthermore, Kapunan,J. was inclined towards the advantages of such a scheme, when he observed that only one reliable and tamper-proof I.D. needed to be presented by the cardholder, instead of several identification papers in the transaction with Government agencies. He further observed that the new system would promote, facilitate and speed up legitimate transactions with Government offices as well as with private and business entities. The case of Philippines is similar to that of India, if not exactly the same. The UIDAI was constituted in pursuance of

85 Ople vs. Torres 293 S.C.R.A. 141 (1998).

${ }^{86} I d$. See also, Sloan, I. Law of Privacy Rights in a Technological Society, p. 6 [1986]. 
a Government of India notification-the noticeable difference being that in Philippines, the judgment was delivered before the Parliament brought out a statute. In India, the Government was able to bring the Act into force, by introducing it in the Parliament as a Money Bill. Philippines is not the only country where the highest Constitutional Court interceded to negate such a scheme. In France, the highest Constitutional authority i.e. Constitutional Council, through a petition by more than 200 opposing Parliamentarians, held unconstitutional a 10-Articles law passed by the lower house of the French Parliament (National Assembly), which proposed new biometric ID for its citizens. ${ }^{87}$ The Court herein declared four Articles of the Identity Protection Act as unconstitutional along with certain parts of two more Articles. The Court acknowledged that there is a justified ground of general public interest, to improve the efficiency of the fight against fraud. However, the Court was of the view that traces of such biometric data are likely to be left unintentionally by the person, or collected without his knowledge. Building on this premise, the Court held that the impugned Articles are an infringement of the citizens' rights and 'that it cannot be regarded as proportionate to the aim pursued.'

It has not always been the Courts who restricted or did away with such schemes. The Governments of various nations have taken affirmative action to achieve similar ends. In the instance of U.K., the Identity Cards Act, 2006, was proposed with the aim of facilitating a secure and reliable recording of registrable facts of individuals and ensuring a convenient method for individuals to prove registrable facts about themselves. ${ }^{88}$ It also provided that an individual may be required to allow his fingerprints, and other biometric information, to be taken and recorded. ${ }^{89}$ However, this was repealed via the Identity Documents Act, 2010.90 The Act

87 Decision No. 2012-652 D.C of March 22, 2012; See also, EDRi, France: Biometric ID database found unconstitutional, European Digital Rights, March 28, 2012 https://edri.org/edrigramnumber10-6french-biometricdatabase-unconstitutional/ (last accessed on 19th April, 2018).

$88 \S 3(1)$, Identity Cards Act, Act of Parliament, 2006

89 §5(5) (b), Identity Cards Act, Act of Parliament, 2006

$90 \S 1(1)$, Identity Cards Act, Act of Parliament, 2006 
provided for cancellation ${ }^{91}$ and destruction of any and all information that were recorded in the National Identity Register. ${ }^{92}$ Some $£ 250 \mathrm{~m}$ was spent on developing the national ID programme over a period of eight years and its abolition meant that the Government will avoid spending a further sum of $£ 800 \mathrm{~m}$ over the next decade, ${ }^{93}$ in securing the database. The Secretary of State for the Home Department, Theresa May, stated that "the national identity card scheme represents the worst of the Government. It is intrusive, ineffective and expensive.

In the case of Australia, within a span of three decades after the formulation of an identity database, there were several attempts by the Government to pass a law mandating ID schemes, all of which were met with great resistance and opposition. The Government in the 1980'swanted to introduce a Bill for an Australian Card, on the pretext of preventing losses to tax revenue through its medium. ${ }^{94}$ The Bill, in its essence, was similar to that of Aadhaar, in that it did not mandate the possession of the Australian Card, yet the existence without one proved to be cumbersome and impossible. ${ }^{95}$ In the year 1986, the Labour Government attempted to introduce Australia Card Bill, 1986 thrice - all of which, were rejected inter alia due to its repercussion on civil liberties. The report of the Joint Select Committee on this subject, in the light of past experience in U.S.A. and Canada spelled out that such an identification system shall not be introduced, and the majority expressed "concern at the effect of a national identification system

\footnotetext{
91 §2, Identity Cards Act, Act of Parliament, 2006

92 §3, Identity Cards Act, Act of Parliament, 2006

${ }^{93}$ Identity cards scheme will be axed 'within 100 days', B.B.C. News (May 27th, 2010) http://news.bbc.co.uk/2/hi/8707355.stm\#backupthere (last accessed on 28th March, 2018).

94 Roy Jordan, Law and Bills Digest Section, Identity Cards and the Access Card, Parliament of Australia, (February, 2006). https://www.aph.gov.au/About_Parliament/Parliamentary_Department s/Parliamentary_Library/Publications_Archive/archive/identitycards (last accessed on 15 ${ }^{\text {th }}$ March, 2018).

95 Graham Greenleaf, The Australia Card: towards a national surveillance system, 25, Law Society Journal 1, 2 (1987) https:/ / papers.ssrn.com/ sol3/ papers.cfm?abstract_id=2195493 (last accessed on: 24 $4^{\text {th }}$ September, 2018).
} 
on the nature of Australian society and the civil liberties of individuals in that society". ${ }^{\prime 6}$

Thereupon, such card schemes remained to be a dead issue, until it resurfaced in the wake of the London bombings in mid-2005. The Prime Minister of Australia, John Winston Howard, who strenuously opposed this scheme earlier, reconsidered it and allowed the Identity Card Proposal 2005-06. However, in a Joint Press Conference on 26 $6^{\text {th }}$ April, 2006, the Government announced the discontinuance of any attempt to propose such a scheme because 'the added advantages of an ID card were outweighed by the disadvantages. ${ }^{\prime 97}$ However, in the same press conference, the Prime Minister expressed his intention to introduce an access card, containing a smart chip, which was to replace other existing cards to avail health and welfare services.98 Consequently, a Human Services (Enhanced Service Delivery) Bill, 2007 was introduced aiming to establish a framework for the Health and Social Service Access Card. There were extensive arguments on the issues of privacy revolving around this Bill, with many Member of Parliaments including Ms. Anna Burke, Ms. Kelly Hoare, Mr. Warren Snowdon and Ms. Annette Ellis being on the forefront to raise this issue during the Second Hearing of Human Services (Enhanced Service Delivery) Bill, 2007 held on 27th day of February, 2007. The Access card scheme was eventually abandoned by the newly elected Government, in December 2007.99

96 The Parliament of the Commonwealth of Australia, Report of the Joint Committee on an Australia Card, May 1986https:// www.aph.gov.au/ Parliamentary_Business/Committees/Senate/Significant_Reports/auscar d/report/index (last accessed on 19 ${ }^{\text {th }}$ March, 2018).

97 Transcript of the Prime Minister the Hon John Howard MP Joint Press Conference with the Attorney-General, the Hon Philip Ruddock MP and the Minister for Human Services, the Hon Joe Hockey MP, Parliament House, Canberra, Beaconsfield Gold Mine, access card; Solomon Islands, April $26^{\text {th }}, 2006$ https://parlinfo.aph.gov.au/parlInfo/ search/ display/ display.w3p;query=Id:\%22media/pressrel/NNGJ6\%22 (last accessed on $28^{\text {th }}$ August, 2018).

${ }^{98}$ Id.

${ }_{99}$ Electronic Frontiers Australia Access Card/ National ID card, (February 10th, 2008) https://www.efa.org.au/Issues/Privacy/accesscard.html (last accessed on 23rd March, 2018). 
Furthermore, during the passage of the bill in the Rajya Sabha, the Finance Minister Mr. Arun Jaitley drew an analogy between the Social Security Number (SSN) in the United States and Aadhaar, terming the legislations in respect of these, as 'similar' legislations. ${ }^{100}$ It therefore becomes pertinent to look into the merit of this argument. Despite the comparison, there are significant differences between them. SSN does not have a biometric identifier attached to it and neither does it support authentication.101 Assuming arguendo that the argument of Hon'ble minister holds any water, and then too, it is fitting to mention that, there are various laws in the U.S.A. to restrict the use of SSN. Federal laws that require the use of an SSN, generally limit its use to the statutory purposes described in each of the laws. ${ }^{102}$ For example, the Internal Revenue Code, which requires the use of SSNs for certain purposes, declares tax return information, to be confidential and prescribes both civil and criminal penalties for unauthorized disclosure. ${ }^{103}$ Besides, with SSNs being identified as the universal identifiers, its dangers were recognized early on, and the Congress passed the Privacy Act of 1974, 104 to curb these dangers. Moreover, in spite of several Federal and State laws being in place to restrict its use, SSN has exposed itself to gross misuse including identity theft. It was estimated by the Federal Trade Commission that over a period of one year, around 10 million people, who constitute 4.6 per cent of the adult population, discovered that they had fallen prey to some kind of identity theft, which translated into reported losses exceeding $\$ 50$ billion. ${ }^{105}$

\footnotetext{
100 Supra note 25.

101 Supra note 77.

102 GAO, Government and Commercial Use of the Social Security Number is widespread, GAO/ HEHS-99-28 (House of Representatives: February 1999) https://www.gao.gov/assets/230/226868.pdf (last accessed on 27th March, 2018).

${ }^{103}$ Id.

104 O.L.R. Research Report, Social Security Number Identifiers,(The Connecticut General Assembly: October 18 ${ }^{\text {th }}$, 1994) https:// www.cga.ct.gov/ PS94/rpt/olr/htm/94-R-0864.htm (last accessed on 27th August, 2018).

105 GAO, Social Security Numbers: Federal and State laws restrict use of SSNs, yet gap remains, GAO-05-1016T (New York State Assembly: September
} 


\section{The Constitutional Validity of Aadhaar}

Technology has rapidly altered the course of our life and reshaped our fundamental understanding of information. This has resulted almost in a sort of a permanent storage of information in some way or the other, making it difficult to begin life again by giving up past mistakes. ${ }^{106}$ Thus, apart from admitted advantages of technology, there are few drawbacks limitations to it. The nine-judge Bench in the Privacy judgement was conscious of the downside of technology, which is explicit in the concurring judgment of Justice Sanjay Kishan Kaul wherein his lordship observed that “technology has made it possible to enter a citizen's house without knocking at his/her door and this is equally possible both by the State and non-State actors." Our quest for technology should not be oblivious to the country's real problems: social exclusion, impoverishment and marginalisation. ${ }^{107}$

The Privacy judgement brings out that the right to privacy is not a mere instrument, but has several intrinsically complicated facets to it. The scope of this right was considerably broadened by the observations made by Justice Dr. D.Y. Chandrachud and Justice Sanjay Kishan Kaul, that the right to privacy is inalienable and inherent in an individual. An equally important aspect of this judgement is that Justice Nariman, refused to accept the Union's contention that the right to privacy is not fundamental in a developing nation, where people do not have access to food, shelter and other resources. This right is available to both the poor and the rich.

The standard of review of privacy violations can be adjudged in light of the judgment rendered by Justice S.A. Bobde, wherein, he states what the standard test has to be maintained while determining the constitutionality of a law. The standard test is a rationality test as expressed in Maneka Gandhi's ${ }^{108}$ case, which requires that the law under which the state interferes with the

2005) https://www.gao.gov/new.items/d051016t.pdf (last accessed on $16^{\text {th }}$ July, 2018).

106 Supra note 11.

${ }^{107}$ Supra note 10.

108 Supra note 46. 
personal liberty of an individual(s), must be fair, just, reasonable and not fanciful, oppressive or arbitrary. In extension, any law purporting to violate privacy has to pass the muster of a three-fold test laid down by Justice D.Y. Chandrachud, in Privacy judgment. The test demanded, at the foremost, that the 'existence of law' be backed by 'legitimate state interest' which will in turn have to pass the 'test of proportionality'. Proportionality principles seek to safeguard citizens from excessive Government measures. ${ }^{109} J u s t i c e$ Dr. D.Y. Chandrachud, in the Privacy judgment, by citing various legal precedents, reiterated that the Courts should tread warily while making evaluations relating to social and economic policy in which they lack expertise.

The focal point of the Aadhaar Act is the use of money belonging to the consolidated fund of the Centre or State governments of India. ${ }^{110}$ In contrast, the reasoning given in the Parliament, by Mr. Jairam Ramesh, that is "Aadhaar does not determine who is eligible and who is not eligible. Please get us rid of this myth. Aadhaar is proof of identity. It says if I am eligible, I am who I am. It does not determine that just because I have my Aadhaar number, I am entitled to subsidy." 111 Therefore, Aadhaar in itself cannot prove to be the single silver bullet to address the concern of leakages in various subsidies and benefits. A collective and integrated approach of the government and its agencies is required on various fronts. Similarly, the Economic Survey 2016-17, which is an official document of the Union Government, notes that "while Aadhaar is designed to solve the identification problem, it cannot solve the 'targeting problem' on its own."112 This is further clear when the same Survey point towards the states' report on authentication failures. The estimates run as high as 49 percent failure rates in Jharkhand, 6 percent in Gujarat, 5 percent in Krishna District in Andhra Pradesh and 37

109 Supra note 10.

110 Supra note 28.

111 Statement by Mr. Jairam Ramesh, The Aadhaar (Targeted Delivery of Financial and Other Subsidies, Benefits and Services) Bill, 2016, Rajya Sabha (16/03/2016) http://rsdebate.nic.in/handle/123456789/659299(last accessed on $21^{\text {st }}$ September, 2018).

112 Government of India, Economic Survey 2016-17, https:// www.thehinducentre.com/multimedia/archive/03193/Economic_Survey _20_3193543a.pdf (last accessed on 12th October, 2018). 
percent in Rajasthan. This has the potential to turn Aadhaar, purported to be a tool for social inclusion, into an instrument of social exclusion. A centralised and inter-linked database like Aadhaar paralyzes one's privacy from every nook and cranny. Therefore, the court has considerably restricted the scope of Aadhaar. However, while upholding Aadhaar, the court did not ventured to decide upon whether such a centralised and interlinked database passes the 'least intrusive' test in achieving its objective. The concurring opinion spells out that this test cannot be insisted upon, because such a comparative analysis of the available identification methods is a question best left to experts. ${ }^{113}$

The Government must have had a justifiable ground for efficiently transferring its subsidies and benefits to the needy, and at face value, Aadhaar appears to be a powerful instrument for achieving this. However it has strayed too far from its originally intended purpose. The absence of a viable alternative means for identification in rolling out the mandatory national identity card, Aadhaar, can have detrimental effects.

Natural factors can alter the biometric information of an individual in course of lifetime. ${ }^{114}$ In 2011, the Standing Committee on Finance was reprimanded for estimated failures of biometric which amounted to as $15 \%$ on account of the dependence of a substantial portion of the population on manual labour. Over time, finger-print can lose its accuracy owing to wear and tear, age, illness or personal injuries. ${ }^{115}$ The iris scan on the other hand, promises reduced errors when compared to fingerprints. However, there are demanding complications attached to it as well. In keeping with the humongous size of population, there is a likelihood of degradation either because of disease or the effect of aging. ${ }^{116}$ Additionally, the iris can also be hindered by specular reflection in uncontrolled

\footnotetext{
${ }^{113}$ Supra note 10.

114 Supra note 10.

${ }^{115}$ Arsalaan F. Rashid, Biometric Finger Print Identification: Is It a Reliable Tool or Not?, Volume 35 Journal of Indian Academy of Forensic Medicine 109, 110 (2013) http:/ / medind.nic.in/jal/t13/i2/jalt13i2p109.pdf

116 P. Grother et al, Temporal Stability of Iris Recognition Accuracy, National Institute of Standards and Technology 1 (2013) https://nvlpubs.nist.gov/nistpubs/ir/2013/NIST.IR.7948.pdf.
} 
lighting situations. ${ }^{117}$ UIDAI has claimed the biometric accuracy to be $99.76 \% .{ }^{118}$ The remaining $0.232 \%$ may seem irrelevant or minute, but in a land where the population 110 crore, this miniscule percentage will result in the exclusion of 27.60 lakh people. This apprehension has been partly dealt with, by the UIDAI circular of 2017.119 This in itself exhibits that, an identity scheme, almost a decade old identity scheme, is still a work-in progress. In retrospect, this highlights one of the particular distresses relating to Aadhaar - that a scheme which should have been much deliberated when it was still on the drawing board and rolled out with wide political consensus, has unfortunately become a political hotpotato.

As per the Lok Sabha unstarred question no. 1788, it is clear that the Government has incurred exorbitant amount towards enrolment and logistics, which is to the tune of Rs. 9,055.73 Crores. At the same time, the Act contains various troublesome provisions which pose a potential threat to privacy. Nonetheless, the mere possibility of the abuse of a provision of law does not invalidate the legislation, per se. ${ }^{120}$ In this regard, the Aadhaar judgement has to a large extent dealt with the apprehension raised and consequently either struck down or read down many of these provisions. However, since the Act was not justified to be passed as a Money Bill, the logical conclusion would have been to strike it down as a whole, while leaving it open for the Parliament to bring in a new legislation in this regard without undermining the authority of Rajya Sabha. This view was also highlighted in the dissenting opinion, ${ }^{121}$ which by extension, holds that until such time that the data is stored, keeping in mind the sensitivity of data, it should not be used by the Government in any manner, whatsoever. Furthermore, in this hue, the Aadhaar judgment has also read down

117 Nancy Yue Liu, Bio-Privacy: Privacy Regulations and the Challenge of Biometrics, 68 A Glass House Book (2012).

118 Supra note 10.

${ }^{119}$ Supra note 65.

120 A. Thangal Kunju Musaliar v. Venkatachalam Potti, Authorised Official and Income Tax Officer and Anr., A.I.R. (1956) S.C. 246; Sushil Kumar Sharma v. Union of India, (2005) 6 S.C.C. 281.

121 Supra note 10. 
section 27(1) of Aadhaar (Authentication) Regulations, 2016 which allowed the authentication records to be archived for five years. ${ }^{122}$ The court found it to be arbitrary and has held that such records cannot be kept beyond a period of six months.

The Aadhaar judgment does not deal completely with the concerns relating to Aadhaar. The judgment has set a legislative agenda, and it is yet to be seen how adequately the Parliament deals with these issues. Concurrently, the paramount and urgent requirement is for the Parliament to bring in a robust regime for data protection. In both the Privacy123and the Aadhaari24judgment, the need for the same has been expressed and the judges had 'hope' for such a framework, when it was intimated that a Committee of Experts be constituted, under the chairmanship of the former judge of the Supreme Court, Mr. Justice B.N. Srikrishna, to deliberate on a data protection regime for India.

The Committee of Experts on Data Protection Framework for India, submitted in July 2018, its report and draft Bill to the Ministry of Electronics and Information Technology. ${ }^{125}$ The Committee inter alia suggested a slew of amendments to the Act, in order to bolster the protection of privacy. Since the Committee was mindful of the fact that it was not entrusted with the task of suggesting amendments to other statutes, it only proposed such amendments as were necessary to bring the allied laws, including the Aadhaar Act, in conformity with the data protection framework. Some suggestions include equipping UIDAI with powers akin to traditional regulator (like SEBI) for enforcement, bolstering financial autonomy, classifying requesting entities into groups to efficiently regulate access of personal data on the basis of necessity, etc. These are certainly welcome changes which will breathe new life into the data protection regime. While the Court cannot theoretically direct the Parliament to enact a law due to the

\footnotetext{
122 Supra note 10.

${ }^{123}$ Supra note 11.

124 Supra note 10.

125 Committee of Experts under the Chairmanship of Justice B.N. Srikrishna, A Free and Fair Digital Economy Protecting Privacy, Empowering Indian http://pibphoto.nic.in/documents/Others/2018727xcxzcx151.pdf (last accessed on $5^{\text {th }}$ August, 2018).
} 
doctrine of separation of powers, there are several authorities that serve as precedents to the contrary. In Gainda Ram EOrs. v. M.C.D. $\mathcal{E} O r s ., 126$ the Supreme Court directed the competent Government to frame an appropriate law to regulate hawking. The Court passed such orders "in exercise of its jurisdiction to protect the fundamental right of the citizens." In addition to this, in Smt. Seema v. Ashwani Kumar, 127 the Court directed the concerned Government to frame appropriate Rules, within a stipulated time, pertaining to the mandatory registration of marriages, which will then be placed before the Court for scrutiny.

As a point of information, it is not the first time that a Group of Experts have submitted their report in this context. The Planning Commission of India constituted a Group of Experts on privacy, under the chairmanship of Mr. Justice A.P. Shah, former Chief Justice of Delhi High Court, which submitted its report in 2012 and no concrete action was taken in the furtherance of its recommendations. The report inter alia suggested the inculcation of a discretionary provision that enables the citizens to either opt into the Aadhaar scheme or not, which was disregarded by the legislature. The inescapable characteristic of Aadhaar needs to be addressed and eradicated.

\section{Conclusion}

The information and the data of citizens stored under the veneer of national interest, extracts oil which was indiscriminately and recklessly ransacked by a drilling machine, namely Aadhaar. At the outset, it may be conceded that earlier there might have been noble intentions in the introduction of Aadhaar, but eventually it has become a force to be reckoned with, especially because of the haste with which the Governments, both previous and current, made it obligatory for virtually everything.

The Aadhaar judgment has certainly put a halt on the Government's quest in making Aadhaar the only means of identification. ${ }^{128}$ The

126 (2010) 10 S.C.C. 715.

127 (2008) 1 S.C.C. 180.

${ }^{128}$ SaubhadraChatterji, Aadhaar may become only identity card in future, to help curb text fraud: Jaitley, Hindustan Times, (April 26 th, 2017) 
Supreme Court's pronouncement on Aadhaar has resulted in both sides of the case claiming a 'qualified' victory. The 1,448 pages judgment offers both positive and negative perspective pertaining to Aadhaar. The judicial review in itself does not invalidate a law or a particular provision, and the Parliament tinkers with the impugned law by incorporating appropriate amendments. ${ }^{129}$ Accordingly, in doing so, the Government will have to regard the object of law, apprehensions posed in judgment, and convenience of the people. ${ }^{130} \mathrm{Be}$ that as it may, a fine tuning of the law is much required with the help of consultative process. It seems to be a major legislative agenda before the Parliament, in the upcoming session. Apart from this, subsequent implementation of it is yet to be witnessed. In the absence of comprehensive privacy legislation, the Government was enabled to use brute force and guile in order to become omnipresent. Therefore, irrespective of the fate of Aadhaar, a much awaited data protection regime, in line with B.N. Srikrishna Committee Report, is a necessity, in the light of rapid technological advancements. While evaluating privacy consequences of biometric technology, it is also important to bear in mind whether the current privacy protections which may be adequate for the present state of technology, will be sufficient in the future. ${ }^{131}$

https://www.hindustantimes.com/india-news/aadhaar-may-become-onlyidentity-card-in-future-says-jaitley/story-EKUQ9QRITNkl6wFFfJA5nJ.html (last accessed on $12^{\text {th }}$ June, 2018).

129 J. Mitchell Pickerill, The Supreme Court and Congress: What happens in Congress after the Court Strikes Down Legislation?, 7 American Bar Association 10

https://www.americanbar.org/content/dam/aba/images/public_education /supremecourtcongress.pdf.

${ }^{130}$ Kumar Uttam, Supreme Court Order on Aadhaar Lays Good Governance Road Map, Says Ravi Shankar Prasad, Hindustan Times (September 26 ${ }^{\text {th }}, 2018$ ) https://www.hindustantimes.com/india-news/supreme-court-order-onaadhaar-lays-good-governance-road-map-says-ravi-shankar-prasad/storyX1ITe9K9KB64JeZ6k1Lt2I.html (last accessed on: 29th September, 2018).

${ }^{131}$ Supra note 10. See also, Robert Gellman, Privacy and Biometric ID Systems: An Approach Using Fair Information Practices for Developing Countries, Centre for Global Development (2013) https:// www.cgdev.org/ sites/ default/ files/ privacy-and-biometric-ID-systems_0.pdf (last accessed on: $5^{\text {th }}$ October, 2018). 